\title{
Erratum to: Bilateral giant adrenal myelolipomas
}

\author{
R. S. Kalidindi, L. Hattingh \\ Department of Radiology, Pinderfields General Hospital, Wakefield, United Kingdom
}

\section{Erratum to: Abdom Imaging (2006) 31:125-127 DOI 10.1007/s00261-005-0014-4}

This article was inadvertently published a second time under DOI: 10.1007/s00261-006-9096-x.

Official publication is under DOI: 10.1007/s00261-005-0014-4 appearing in Abdom Imaging (2006) 31:125-127.

The online version of the original article can be found under doi:10.1007/s00261-005-0014-4.

Correspondence to: R. S. Kalidindi; email: ksvraju@hotmail.com 